\title{
Wootz: Cast Iron or Steel?
}

\author{
D. A. Sukhanov ${ }^{1 *}$, N. V. Plotnikova ${ }^{2}$ \\ ${ }^{1}$ ASK-MSC Company, Moscow, Russia \\ ${ }^{2}$ Novosibirsk State Technical University, Novosibirsk, Russia \\ Email: *Dr.Sukhanov@mail.ru,n.plotnikova@corp.nstu.ru
}

How to cite this paper: Sukhanov, D.A. and Plotnikova, N.V. (2016) Wootz: Cast Iron or Steel? Materials Sciences and Applications, 7, 792-802.

http://dx.doi.org/10.4236/msa.2016.711061

Received: September 29, 2016

Accepted: November 26, 2016

Published: November 29, 2016

Copyright $\odot 2016$ by authors and Scientific Research Publishing Inc. This work is licensed under the Creative Commons Attribution International License (CC BY 4.0).

http://creativecommons.org/licenses/by/4.0/

\begin{abstract}
It is shown that the excess carbide phase in Wootz is of an unusual nature origin that differs from the excess phase of secondary cementite, ledeburite and primary cementite in iron-carbon alloys. It is revealed that the morphological features of excess cementite in Wootz lie in the abnormal size of excess carbides having the shape of irregular prisms. It is discovered that the faceted angular carbides are formed within the original of metastable ledeburite, so they are called "eutectic carbides". It was found that angular eutectic carbides in the Wootz formed during long isothermal soaking at the annealing and subsequent deformation of ledeburite structures. It is revealed that carbon takes up 2.25\% in Wootz (in the region of white cast iron), while none in its structure of crushed ledeburite. It is shown that the pattern of carbide heterogeneity consists entirely of angular eutectic carbides having an irregular trigonal-prismatic morphology. It is shown that Wootz (Damascus steel) is non-alloy tool steel of ledeburite class, similar with structural characteristics of die steel of ledeburite class and high-speed steel, differing from them only in the nature of excess carbide phase.
\end{abstract}

\section{Keywords}

Wootz, Damascus Steel, Bulat, Tool Steel

\section{Introduction}

In the modern industry, we do not apply iron-carbon alloys with a carbon content of more than $2 \%$. It is believed that these alloys have low ductility, shallow depth hardenability and low heat-resistant of cementite carbides. Moreover, these alloys are susceptible to overheating and have a higher tendency to decarburization. On this basis, the production of quality of the tool from the iron-carbon alloys, which is the carbon content in the region of white cast iron, is impractical.

The blades from Damascus steel were attributed to the unusual properties. Durability under multiple dynamic loads combined with high wear resistance of the cutting edge 
to spalling. High strength combined with tremendous elasticity. Even today, modern tool steel cannot boast of such a set of design properties. In this is the historical value of Wootz for the modern tool industry.

In the classification of tool steels, the term "Wootz" is almost never used. Wootz became a myth of the past which had no future. This is because there is no single coherent theory of the structural components of Wootz. A huge number of imitations, imitating Wootz pattern, have low performance characteristics. According to Prof. Taganov [1], low quality Eastern Damascus steels led to widespread cessation of the production of Indo-Persian blades in the 18th century.

In scientific literature, there are many conflicting data on the chemical composition and mechanical properties of Damascus steel (Wootz). Some authors [2] [3] [4] consider that the composition of Damascus steel (Wootz) is high-purity hypereutectoid steel with a carbon content of from $1 \%$ to $2 \%$. Excess carbide phase in these steels is an abnormally large coagulated grain of secondary cementite. Other authors [5] [6] [7] think that the Damascus steel (Wootz) in its composition is closer to white cast iron with a carbon content of from 2\% to 3\%. Excess carbides represent crushed ledeburite. However, spheroidization excess of secondary cementite and crushing of ledeburite eutectic not bring us closer to understand the essence of Wootz.

The aim of this work is to study the morphological features of excess structural phases in Wootz. Question about the origin of the excess carbides in Wootz is one of the most interesting and important in the analyzed problem. It has not only scientific but also practical significance. Knowing the answer to that question is possible to manage the whole complex of mechanical and physical properties of Wootz.

\section{Materials and Methods}

Structural components of iron-carbon alloys consist of dendrites of solid solution and excess phases of cementite and of ledeburite. The determining factor for the deformation plasticity is the cleanliness of these structural components. All other impurities except carbon must be in the hundredths and thousandths fractions. Nowadays, understanding of the purity of the alloy does not exclude the presence of products of deoxidation with manganese or silicon. The presence of manganese more than $0.2 \% \mathrm{Mn}$ reduces the growth of dendrites of austenite during solidification of the melt, changes the chemistry of carbide, perlite stabilizes at the high-temperature annealing.

The object of the research was chosen the high-carbon alloys after melting, which in the structure have excess carbide phase, shown in Figure 1.

Melting was carried out in a vacuum furnace without deoxidation in the Federal State Unitary Enterprise (FSUE) I.P. Bardin Central Research Institute for Ferrous Metallurgy (Moscow). The chemical composition of the alloys is presented in Table 1. The chemical composition of the alloy controlled with the help of optical emission spectrometer ARL 3460 type on the Novosibirsk State Technical University (Novosibirsk). In the marking of alloys letters and numbers signify the following: $B U$ is a Bulat (Wootz) containing not more than $0.1 \%$ of manganese and silicon (each individually); Number 

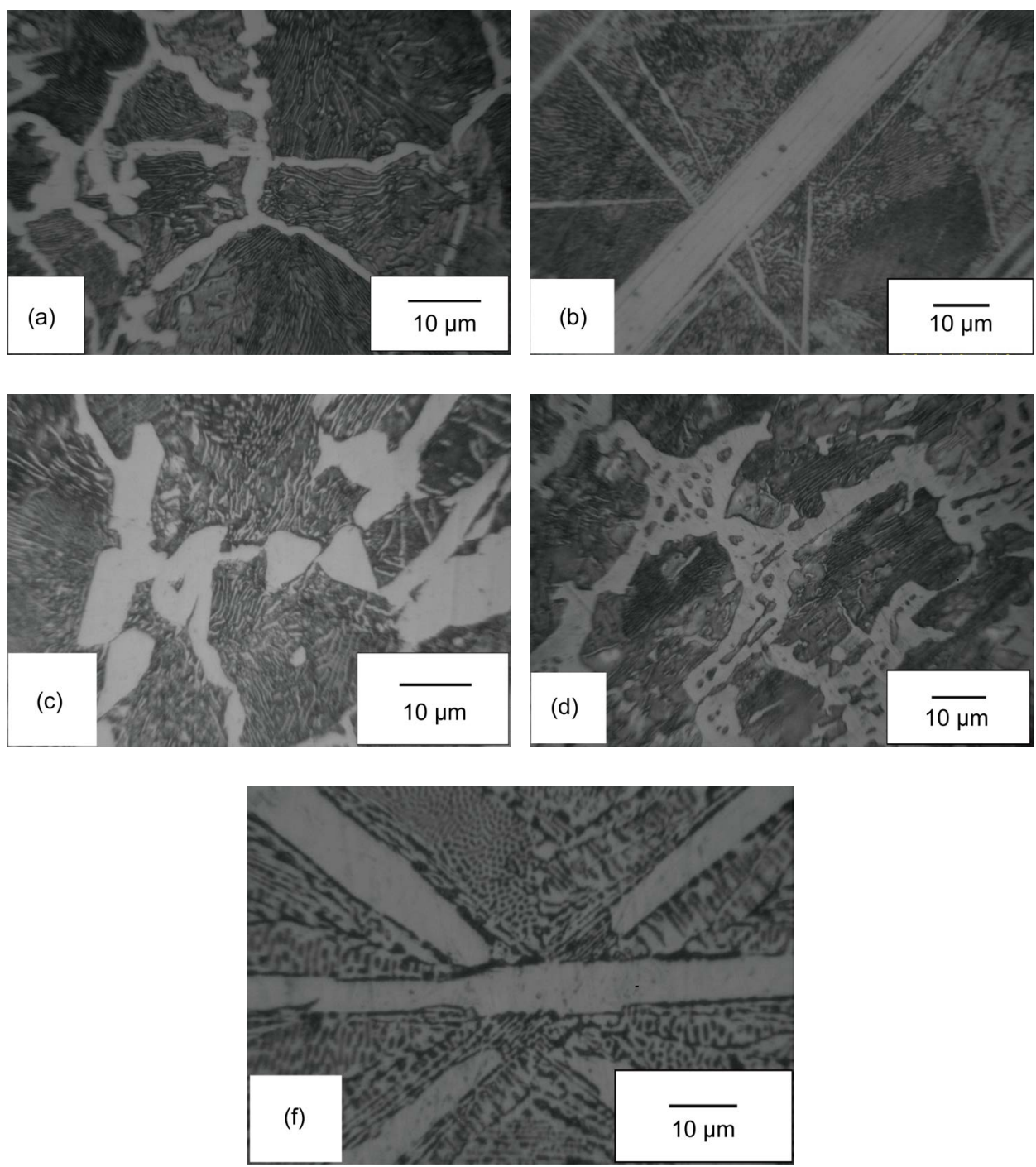

Figure 1. Structure of high-carbon alloys after melting: (a) BU16A (matrix is a lamellar pearlitic; excess carbide is a secondary cementite network); (b) BU22A (matrix is a lamellar pearlitic; excess carbide is a Widmannstatten cementite); (c) BU22A (matrix is a lamellar pearlitic; excess carbide is a metastable ledeburite); (d) BU27A (matrix is a lamellar pearlitic; excess carbide is a ledeburite network); (f) Cast Iron (matrix is a ledeburite; excess carbide is a primary cementite).

Table 1. Test High-carbon alloy chemical composition.

\begin{tabular}{ccccccc}
\hline \multirow{2}{*}{ Alloys } & \multicolumn{6}{c}{ The contents of chemical elements, \% } \\
\cline { 2 - 7 } & $\mathrm{C}$ & $\mathrm{Si}$ & $\mathrm{Mn}$ & $\mathrm{P}$ & $\mathrm{S}$ & $\mathrm{V}$ \\
\hline BU16A & 1.62 & 0.069 & 0.026 & 0.002 & 0.004 & $\cdots-$ \\
BU22A & 2.25 & 0.065 & 0.024 & 0.002 & 0.004 & --- \\
BU27A & 2.70 & $<0.1$ & $<0.1$ & 0.003 & 0.003 & $\cdots$ \\
CAST IRON & 4.53 & 0.082 & 0.51 & 0.021 & 0.025 & 1.1
\end{tabular}

All the rest elements in hundredths and thousandths fractions 
is the average carbon weight fraction (wt.\%); $A$ is a high-quality alloy containing not more than $0.03 \%$ sulfur and phosphorus (each individually).

Alloy structure BU16A is a matrix lamellar pearlitic with excess carbide phase in the form of a continuous of secondary cementite network, located on the borders of the former austenitic grains (Figure 1(a)). Alloy structure BU22A is a matrix lamellar pearlitic with excess carbide phase in the form of Widmannstatten cementite (Figure 1(b)) and of metastable ledeburite (Figure 1(c)). Alloy structure BU27A is a matrix lamellar pearlitic with excess carbide phase in the form of continuous ledeburite network (Figure 1(d)). The structure of hypereutectic Cast Iron is a matrix ledeburite placed in it by plate of primary cementite (Figure $1(\mathrm{f})$ ).

The deformation of the alloys was performed by means of forging in the temperature range from $850^{\circ} \mathrm{C}$ to $650^{\circ} \mathrm{C}$. Structural investigations were carried out using an optical microscope of a series METAM RV-21-2 in the zoom range from 50 to 1100 fold. Deeper structural investigations were carried out on scanning electron microscope CarlZeiss EV050 XVP using microanalyzer EDS X-Act.

\section{Results and Discussion}

Excess carbides in the Wootz is distributed in globular matrix is uneven, forming a texture in the direction of deformation forging (Figure 2). The microstructure of Wootz is a ferritic matrix with uniformly distributed in it a secondary cementite, having the right round or oval shape without distinct angles, a particle diameter of about $0.2, \cdots$, $0.6 \mu \mathrm{m}$ and unevenly is distributed abnormally large carbides having an irregular trigonal-prismatic morphology with sizes ranging from $5 \mu \mathrm{m}$ to $20 \mu \mathrm{m}$ (Figure 2(b)). Pattern carbide in homogeneity consists entirely of carbides of angular prismatic shape. Crushed ledeburite in the structure of Wootz is not detected.

As a result, it is possible to conclude that the in Wootz of excess cementite phase has the unusual nature of the origin, which is different from the excess phases of secondary cementite, ledeburite and primary cementite. Morphological feature of this cement lies in the abnormal size of the carbides having the shape of irregular prisms. Angular carbides in the Wootz are similar to the shape of eutectic carbides of ledeburite tool steels [8] [9].

The mechanism of formation of massive angular carbides in pure iron-carbon alloys of the type Wootz is still unclear. Prof. Kremnev [10] believes that the angular carbides
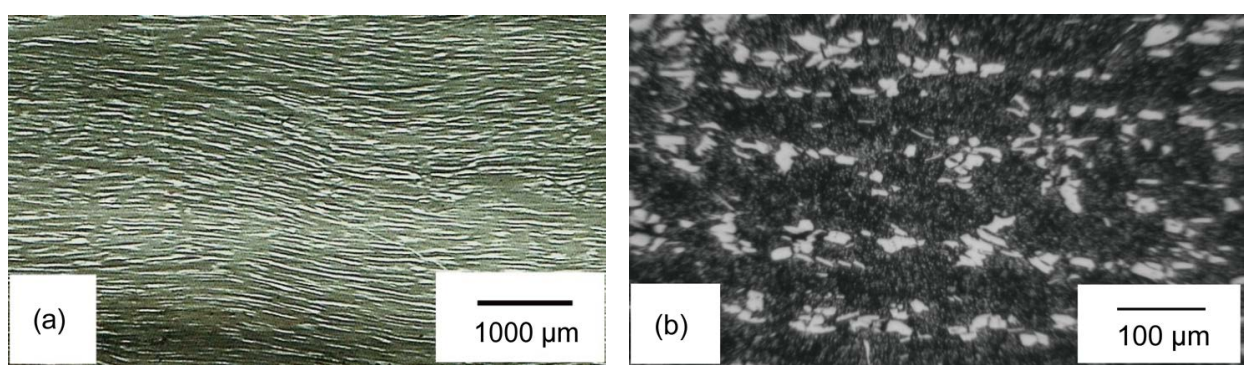

Figure 2. Macrostructure (a) and microstructure (b) of Wootz. 
are the product of unfinished process in spheroidizing. In our opinion, this approach is incomplete, as there are at least two kinds of process of formation of excess carbides in the form of separate particles. First, the spheroidization of carbides-carbides has the correct round or oval shape without distinct corners. Spheroidizingis expected to particles of the second phase obtained after decomposition of austenite. Second, the faceted (cut) carbides-carbides have an irregular trigonal-prismatic morphology. The process the faceted of carbides inherent excess phase formed after the collapse of eutectic. Management of the processes of spheroidizing of secondary cementite and faceted of carbides eutectic during thermomechanical processing allows obtaining alloys with wear resistance in white cast iron and elasticity as spring steel.

What is the mechanism of formation of angular carbides in pure iron-carbon alloys? To answer this question, we examined the alloys BU16A, BU22A and BU27A with a minimum amount of impurities, chemical composition of which is shown in Table 1. The deformation of the alloys was performed by means of forging in the temperature range from $850^{\circ} \mathrm{C}$ to $650^{\circ} \mathrm{C}$.

In all alloys the matrix is lamellar pearlite with interlamellar spacing from $0.6 \mu \mathrm{m}$ to $1.0 \mu \mathrm{m}$ (Figures 1(a)-1(d)). The morphology of the lamellar perlite has a low elasticity compared to globular pearlite. When heating under forging to the temperature of the $\mathrm{A}_{1}$ lamellar pearlite is transformed into austenite. In the process of forging Wootz gradually cooled in the temperature range from $850^{\circ} \mathrm{C}$ to $650^{\circ} \mathrm{C}$, reaching in the intercritical interval temperature dynamic recrystallization of austenite. Of solid solution of austenite, cementite is allocated in the form of circular uniformly distributed particles with a size of about $0.2 \mu \mathrm{m}$. As a result, almost all presented alloys formed sorbita matrix, which leads to a sharp increase in the elastic properties.

Structure of excess carbide before forging in the alloys is significantly different. We were interested in how the morphological features of excess cementite formed angular carbides, having high heat resistance compared with secondary carbides of cementite. Study the influence of morphology of the excess carbide phase, depending is cementite network (Figure 1(a)), Widmannstatten cementite (Figure 1(b)), metastable ledeburite (Figure 1(c)) and ledeburite network (Figure 1(d)).

Hypereutectic white cast iron are not considered because the matrix is brittle eutectic component is a ledeburite with disposed therein a needle of primary cementite (Figure $1(f))$. In the alloy at lower temperatures of forging cannot be deformation.

\subsection{Cementite Network}

One of the drawbacks of hypereutectoid alloy BU16A is are sensitive to overheating. By slow cooling the alloy at a rate of $10^{\circ} \mathrm{C}$ per hour, austenite grains grow to large sizes, some of them reach 50, $\cdots, 100 \mu \mathrm{m}$. Excess carbon falls out of solid solution of austenite forming at the grain boundaries of the solid cementite network with a thickness of $2 \mu \mathrm{m}$ to $5 \mu \mathrm{m}$ (Figure 1(a)). It the cementite network forms a mesh-like patterns crystallization after the etching. Morphology of cementite network contributes to the embrittlement of high carbon alloys under pressure treatment, limiting its scope. Experience 
shows that whenever in the structure of Wootz is partially preserved mesh secondary cementite, fracture occurs at the grain boundaries. Thus, the inadmissibility in the microstructure of Wootz of cementite network is obvious.

In the microstructure of Damascus steel, crushing of cementite network is phenomenon very rare and usually considered marriage. To eliminate used high-intensity forging in the temperature range from $850^{\circ} \mathrm{C}$ to $650^{\circ} \mathrm{C}$. Before forging of cementite network is continuous with the same cell size in all directions (Figure 1(a)). After forging the crushing of cementite network is lengthened, preserving the orientation along the axis of deformation (Figure 3(a)). The destruction of cementite network takes place with the formation of detached particles are mostly spherical and oval. The volume fraction of excess cementite particles does not exceed $10 \%$. This mechanism of fragmentation of cementite network is described in details Sherby and Wadsworth [3]. Microstructure alloy with crushed of cementite network, which even having of patterned surface, cannot be considered Wootz.

On the micrograph, it shows individual allocation of large carbides with a size greater than 20 microns (Figure 3(b)). In his monograph Professor Golikov [11] showed that such clusters of carbides are not that other, as the plots of the deformed metastable ledeburite. Large of carbide formation is retained after annealing at a temperature of over $1000^{\circ} \mathrm{C}$, whereas the secondary carbides at this temperature are dissolved in the austenitic matrix. Increased heat resistance of large angular carbides in comparison with secondary carbides of cementite will expand the scope of high-purity hypereutectoid alloy type BU16A. This requires an increase in their volume fraction and reduces the impact of excessive secondary phases of cementite.

\subsection{Widmannstatten Cementite}

Professor Taran et al in their article [12] wrote that the plates of Widmannstatten cementite consist of separate layers. Layering is clearly visible when considering the structure cementite in the alloy BU22A which shown in Figure 1(b). The thickness of
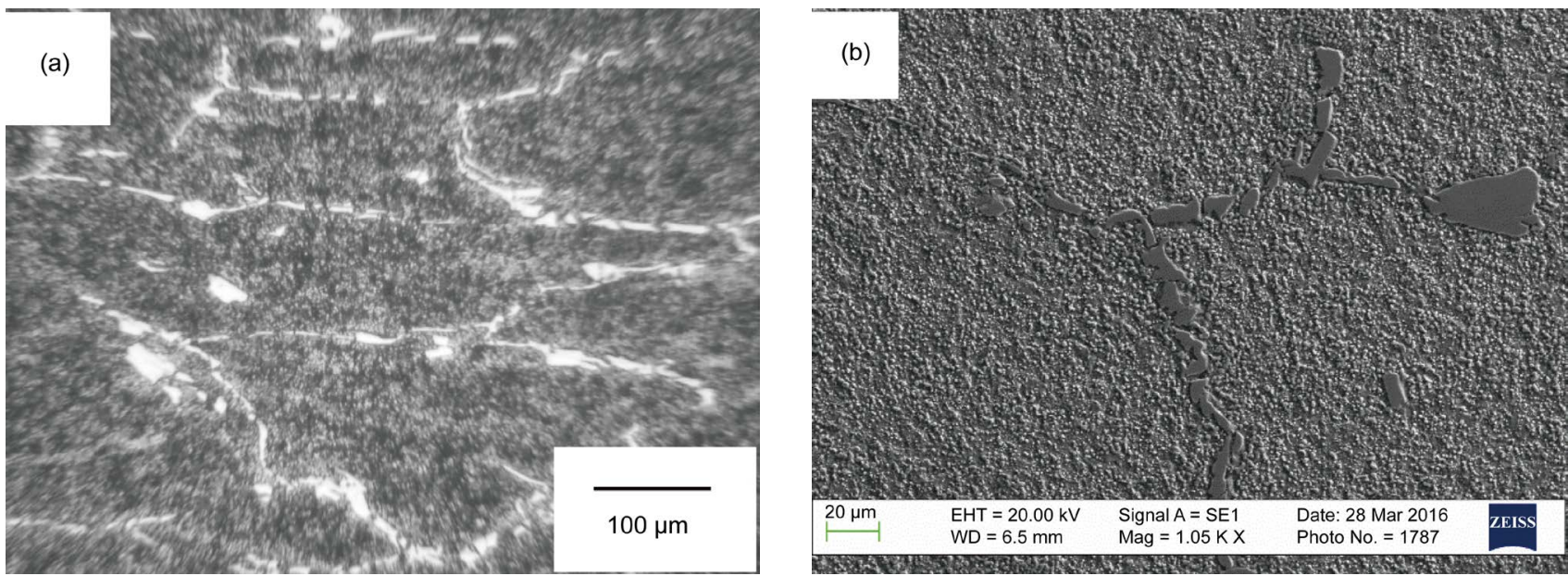

Figure 3. Forging alloy BU16A with excess phase in the form of cementite network: (a) optical microscopy (deformed of cementite network); (b) electron microscope (crushing of cementite network). 
the plates Widmannstatten cementite is about $10 \mu \mathrm{m}$. The thickness of individual layers in the plate is about $0.6-1.0 \mu \mathrm{m}$. The number of layers in the plates ranges from one to several dozen. The layers typically consist of blocks in the shape of rectangular bars, misaligned by the angle $1^{\prime}, \cdots, 2^{\prime}$. The boundaries between the layers are enriched with microdefects of the type of dislocations.

Forging alloy BU22A in the temperature range from $850^{\circ} \mathrm{C}$ to $650^{\circ} \mathrm{C}$, in which morphology the excess carbide phase has the Widmanstatten cementite, is fraught with certain difficulties. At the deformation Widmanstatten cementite are not destroyed fragile but separating down by zones of conjugation of the layers due to the sharp increase in the interfacial region the dislocation density. In areas of high density of dislocations, plates of cementite are divided into separate blocks and particles. Deformed alloy structure with of Widmanstatten cementite is similar to the intertwine bush (Figure 4). The morphology of the cementite has a low thermal stability and contributes to a drastic embrittlement of the steel. In order to give the alloy BU22A elasticity and increase the wear resistance of the tool cutting edge for a longer time, need another morphology of the carbide.

\subsection{Metastable Ledeburite}

The characteristic morphological feature of metastable ledeburite is that it compared to lamellar and cell ledeburite white cast iron, contains in its structure a reduced amount of micropores and has no pronounced layering, so its composition is not ledeburite, but not angular eutectic carbide (Figure $1(\mathrm{c})$ ). In the alloy BU22A, the volume fraction of the excess phase in metastable ledeburite formations is about $20 \%$.

In the process of forging in the temperature range from $850^{\circ} \mathrm{C}$ to $650^{\circ} \mathrm{C}$, metastable ledeburite is under the influence of the normal compressive stress of austenite and the shear stress of deformation. In the process of deformation around carbide, conglomerates
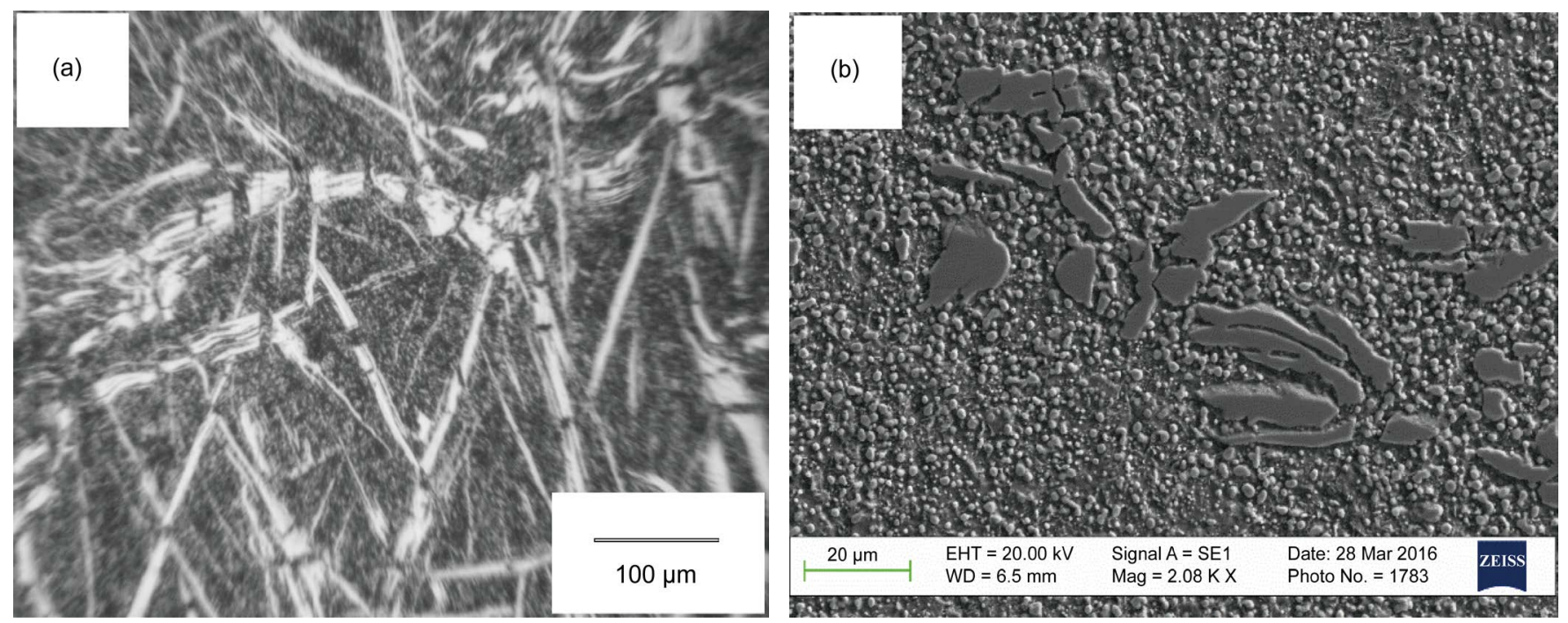

Figure 4. Forging alloy BU22A with excess phase in the form of Widmannstatten cementite: (a) optical microscopy (deformed of Widmannstatten cementite); (b) electron microscope (crushing of Widmannstatten cementite). 
accumulate defects such as dislocations. It results in less stable carbides transforming into more stable carbides of prismatic shape.

The essence of the hypothesis about the formation of carbides of prismatic shape is in the restructuring of the crystal lattice of intermediate metastable cementite carbides in which the carbon atoms are packed in a trigonal-prismatic complex. According to Professor Nizhnikovskaya [13], decrease resistance inside the lattice of cementite in the process of transformation is associated with the weakening of the barriers of the PeierlsNabarro.

The essence of transformation of metastable ledeburite in the faceted prismatic carbides is in that a new phase of carbide is formed inside the source, and the growth of carbides is due to the migration of interphase boundaries. The growth of surplus carbides is a diffusion redistribution of the components between the carbide and solid solution of austenite. The migration of interphase boundaries in the process of transformation leads to the separation of excess prismatic carbides at the parts. Completed the process of recrystallization of metastable ledeburite in angular carbide is irreversible. This process resembles of a gingalloys.

Metastable ledeburite, which formed during long-term isothermal exposures, is the most promising for the formation of faceted carbide cementite of prismatic shape. The structure of these alloys after deformation consists of sorbitol matrix with unevenly distributed therein-large particles of cementite having an irregular trigonal-prismatic morphology with sizes ranging from $5.0 \mu \mathrm{m}$ to $20 \mu \mathrm{m}$ (Figure 5). Undoubtedly, this alloy structure is fully consistent with Wootz.

\subsection{Ledeburite Network}

Cast alloy structure BU27A is characteristic of white iron (Figure 1(d)). Excess phase ledeburite located at the grain boundaries in the form of a network. The grain size is about $50-100 \mu \mathrm{m}$. The volume fraction of ledeburite network is about $30 \%$. The
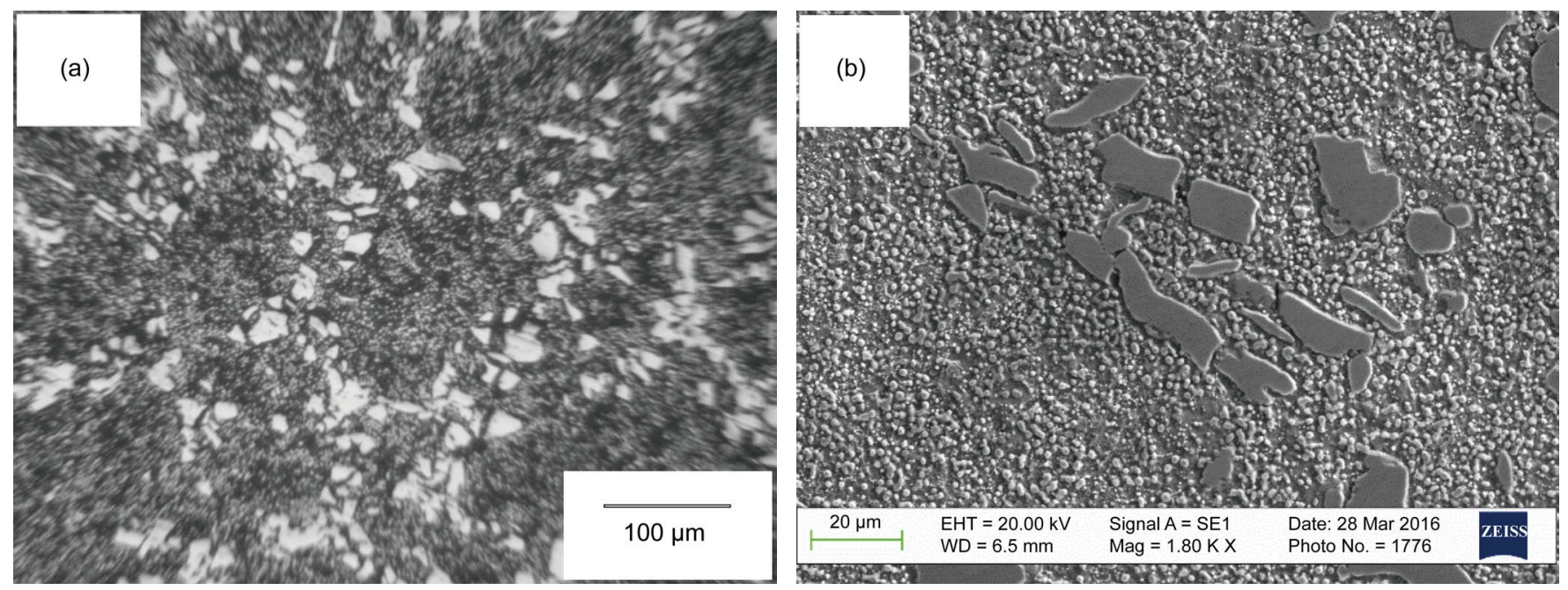

Figure 5. Forging alloy BU22A with excess phase in the form of metastable ledeburite: (a) optical microscopy (eutectic cementite); (b) electron microscope (eutectic cementite). 
thickness of ledeburite is in the range of $20-30 \mu \mathrm{m}$.

If ledeburite network is continuous, then level of plasticity of the alloy is approaching the level of the eutectic component. This is because grains of solid solution are isolated from each other fragile of eutectic. According to Professor Nizhnikovskaya [14], deformation hypoeutectic white cast iron is possible when the maintained contact between the dendrites of the solid solution. Such contact appears in alloys with the degree of eutectic below $30 \%$, which corresponds to a carbon content of approximately 2.5 2.7 percent. Other fundamental factors improve the ductility of white cast irons under deformation are the lack of structure Widmanstatten of cementite, and purity of the iron matrix. White cast iron in its chemical composition must be highly pure alloy of iron and carbon (all other impurities are in the hundredths and thousandths fractions). Only in this case, the deformation of white cast irons is due to the carbide transformation in which a peak is observed plasticity. The essence of this process lies in the recrystallization of ledeburite in the process of plastic deformation in a stable phase of carbide of prismatic morphology (Figure 6).

However, the most common is the idea that eutectic carbides are formed during the deformation of crushing ledeburite into separate fragments (Figure 6(a)). This traditional view on the formation of carbides of prismatic morphology is described in detail in monograph of Professor Geller [15]. Crushing carbide occurs in places of a congestion of dislocations.

To obtain Wootz from cast alloy BU27A need more technological operations than from cast alloy BU22A. In fact, for the transformation of ledeburite in the eutectic carbide require more time and effort. We recommend that before forging to conduct a preliminary high-temperature annealing for the formation of metastable structures of ledeburite. The duration of annealing depends on the heating temperature. For example, at $650^{\circ} \mathrm{C}$ is soaking should be at least 200 hours at $1150^{\circ} \mathrm{C}$ for 2 hours. In fact, the
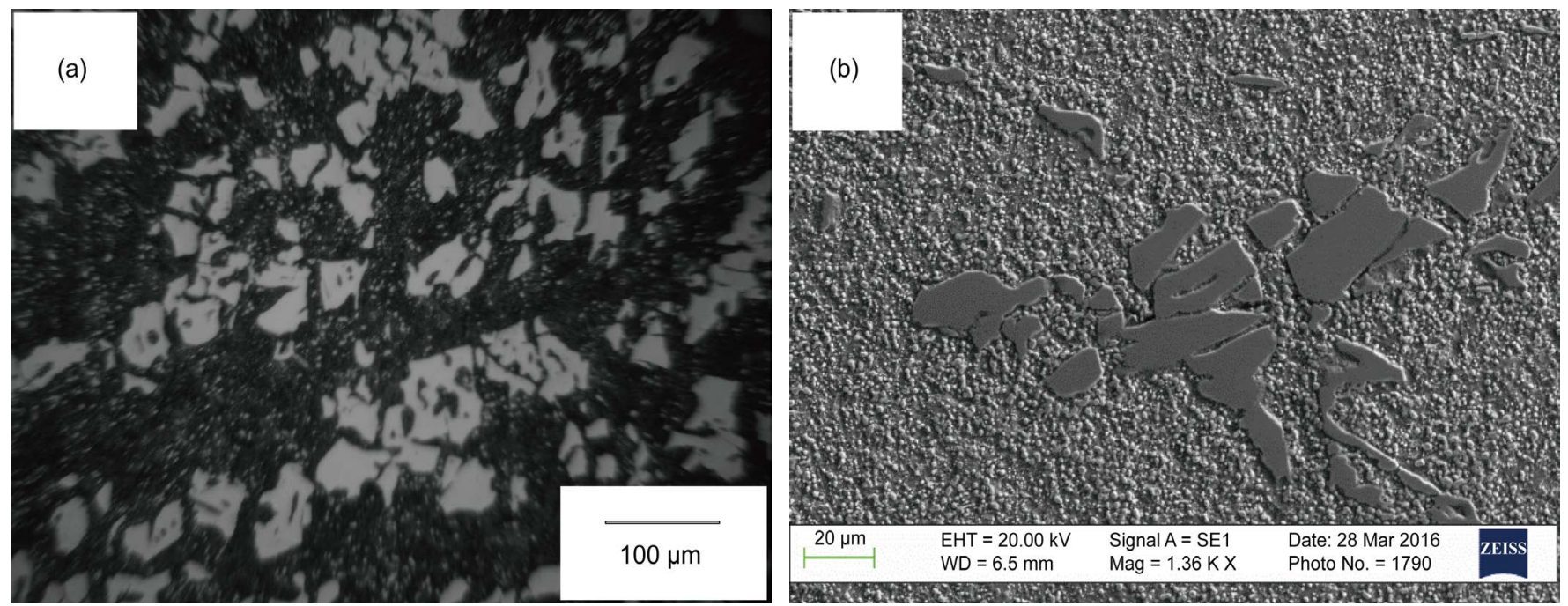

Figure 6. Forging alloy BU27A with excess phase in the form of ledeburite network: (a) optical microscopy (crushing of ledeburite); (b) electron microscope (eutectic cementite). 
alloy BU27A becomes Wootz during isothermal aging at high-temperature annealing (Figure 6(b)). The duration of isothermal soaking is an integral part of the process of faceting and coalescence of the excess of the eutectic carbides. Deformation accelerates the formation of angular eutectic carbides and contributes to their size reduction.

\section{Conclusions}

Structure of the excess phase of cementite in Wootz has the unusual nature of the origin that is different from the excess phases of secondary cementite, cementite of ledeburite and primary cementite. Morphological feature of this cement lies in the abnormal size of the carbides having the shape of an irregular octahedrons and prisms. Angular carbides in Wootz are similar to the shape of eutectic carbides of ledeburite tool steels (Figure 7).

Crushing secondary of cementite network structure or the splitting of Widmanstatten cementite does not lead to the formation of angular eutectic carbides. The eutectic carbides in the Wootz (Damascus steel) are formed during long isothermal soaking at the annealing and subsequent deformation of ledeburite structures.

Management of the processes of spheroidizing of secondary cementite and faceted of carbides eutectic during thermomechanical processing allows obtaining alloys with wear resistance in white cast iron and elasticity as spring steel.

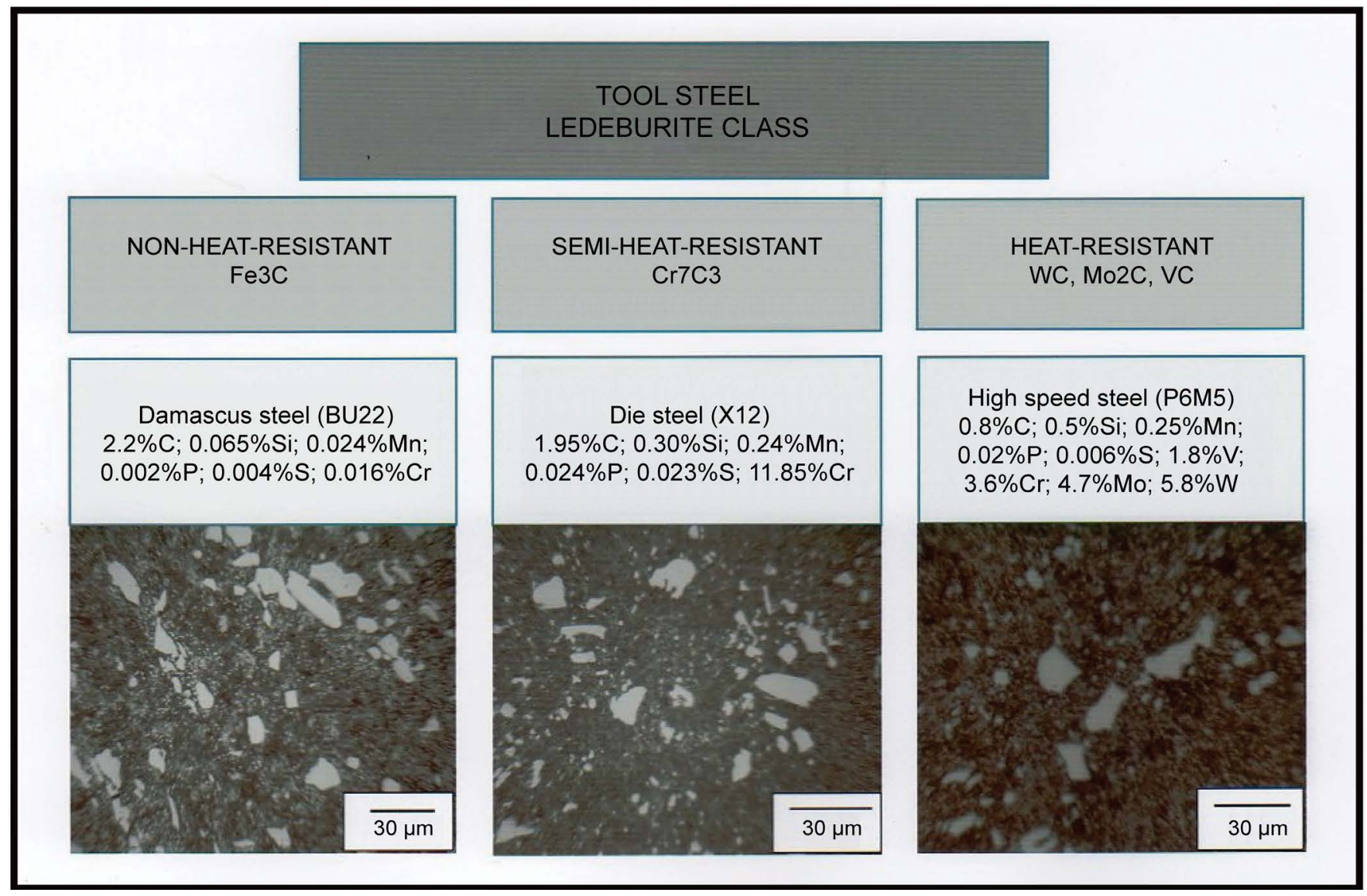

Figure 7. Classification of tool steels ledeburite class of heat resistance of the excess carbides. 
Wootz (Damascus steel) can be described as non-alloy tool steel of ledeburite class, similar with structural characteristics of die steel of ledeburite class and high-speed steel, differing from them only in the nature of excess carbide phase (Figure 7).

\section{References}

[1] Taganov, I.N. (2009) The End of Bulat Legend. Kalashnikov, No. 11, 92-97.

[2] Tavadze, F.N., Amaglobeli, V.G., Inanishvili, G.V. and Eterashvili, T.V. (1984) Electron Microscopic Studies of Bulat. Bulletin of the Academy of Sciences of the Georgian, 113, 601604.

[3] Sherby, O.D. and Wadsworth, J. (1985) Damascus Steel. Scientific American, 252, 112-120. http://dx.doi.org/10.1038/scientificamerican0285-112

[4] Verhoeven, J.D., Pendray, A.H. and Gibson, E.D. (1996) Wootz Damascus Steel Blades. Materials Characterization, No. 37, 9-22. http://dx.doi.org/10.1016/s1044-5803(96)00019-8

[5] Gaev, I.S. (1965) Bulat and Contemporary Iron-Carbon Alloys. MiTOM, No. 9, 17-24.

[6] Gurevich, Yu.G. (2007) Classification of Bulat with Respect to Macro- and Microstructure. MiTOM, No. 2, 3-7.

[7] Schastlivtsev, V.M., Urtsev, V.N., Shmakov, A.V., et al. (2013) Structure of Bulat. FMM, 114, 650-657. http://dx.doi.org/10.1134/s0031918x13070107

[8] Sukhanov, D.A. and Arkhangelsky, L.B. (2016) Damascus Steel Microstructure. Metallurgist, No. 59, 818-822. http://dx.doi.org/10.1007/s11015-016-0178-x

[9] Sukhanov, D.A., Arkhangelsky, L.B., Plotnikova, N.V. and Belousova, N.S. (2016) Morphology of Excess Carbides Damascus Steel. Journal of Materials Science Research, 5, 59-65.

[10] Kremnev, L.S. and Zabolotsky, V.K. (1969) Large Carbides in the Structure of High-Speed Steels. Metal Science and Heat Treatment, 11, 53-58. http://dx.doi.org/10.1007/bf00655176

[11] Golikov, I.N. (1958) Dendritic Liquation in Steel. Metallurgizdat, Moscow.

[12] Taran, Yu.N. and Novik, V.I. (1967) Structure of Cementite in White Cast Iron. Foundry Production, No. 1, 34-38.

[13] Nizhnikovskaya, P.F. (1982) Carbide Transformations in Eutectic Iron-Carbon Alloys. Metals, No. 6, 105-110.

[14] Nizhnikovskaya, P.F. (1984) Structure and Ductility of Eutectic Type Iron-Carbon Alloys. Metal Science and Heat Treatment, 26, 652-657. http://dx.doi.org/10.1007/bf00712550

[15] Geller, Yu.A. (1968) Tool Steels. Metallurgy, Moscow. 
Submit or recommend next manuscript to SCIRP and we will provide best service for you:

Accepting pre-submission inquiries through Email, Facebook, LinkedIn, Twitter, etc. A wide selection of journals (inclusive of 9 subjects, more than 200 journals)

Providing 24-hour high-quality service

User-friendly online submission system

Fair and swift peer-review system

Efficient typesetting and proofreading procedure

Display of the result of downloads and visits, as well as the number of cited articles

Maximum dissemination of your research work

Submit your manuscript at: http://papersubmission.scirp.org/

Or contact msa@scirp.org 